\title{
The Impact of Corporate Social Responsibility on Firm's Financial Performance
}

\author{
Tanvir Ahmed ${ }^{1}$, Babar Zaheer Butt², Waleed Khalid ${ }^{3}$ \\ ${ }^{1} \mathrm{Ph} . \mathrm{D}$ Scholar, Foundation University, Islamabad, Pakistan \\ ${ }^{2}$ Post Doctorate Research Fellow, Tohoku University of Community Service \& Science, Japan \\ ${ }^{3}$ Ph.D Scholar, NUML University, Islamabad, Pakistan \\ tanvirkhan1979@yahoo.com
}

\begin{abstract}
Corporate Social Responsibility (CSR) is now an integral part of business model of most of the modern organizations. Companies are making efforts to play their role in improving society in one or other ways. The scope of efforts ranges from donating money to nonprofit organizations to employing environmental-friendly policies in their workplace. As per the general global perception the corporate sector of Pakistan has been lacking behind in respect of CSR implementation. It has largely concentrated on profit minting rather than taking care of the welfare aspects of employees and other stakeholders. This attitude has affected the business and as a result industry has failed to keep pace with the modern industry. The objective of this study is to analyze the impact of CSR on firm's financial performance. The research therefore predicates that increase in CSR activities of poor CSR firms shall have a negative effect on the company's financial performance. Whereas, Middle CSR firms having a positive relationship with Excess Value (EV) will enhance the project performance, financial stature and future prospect of the firms. However, the firms with the best CSR will always have a positive relationship with the firm's financial performance but its impact will not be observed significantly on the firm's financial condition.
\end{abstract}

Keywords: CSR, corporate sector, financial performance, financial structure

\section{Introduction}

The dialogue continues uninterrupted whether the firms in Pakistan should engage themselves more amicably in socially viable behavior. Whereas the traditional economic dialogueforces the managers to make such decisions which lead to maximize the wealth of a firm's equity. In order to pursue the goal, the managers resort to all sorts of malpractices to maximize the existing value of a firm's and fetch maximum revenues. Since socially responsible activities do not correspond to the aforesaid economic objectives, the financial logic compels to refrain from putting them into practice. At times a narrow focus may suggest the managementto ignore important stakeholders (employees, customers andother stakeholders) which may adversely affect the interests of a firm's equity and also reduce the present value of a firm's cash flows (Yunis, et. al, 2017; Mc William \& Seigel, 2001; Abboud \& Abdul Razek, 2010 \& Friedman, 1970).

No doubt since the advent of industrial revolution and globalization, the role of CSR has gained manifold importance among practitioners, policymakers and in organizations day-by-day (McWilliams and Siegel, 2001; Margolis and Walsh, 2001, 2003; Orlitzky et al, 2003). Resultantly this element has brought forth a new concept in the field of research of the relationship between CSR and firm's value performance and CSR and firm's financial performance etc. Formally, CSR is defined as "the movement aimed at encouraging companies to be aware of the impact of their business on the rest of the society, including their own stakeholders and the environment". Furthermore, by Visser (2008), it is the process by which company or firm continuously contributes toward improving its governance, ethical standards and environmental conditions. The concept of CSR is not new; rather it was introduced in $18^{\text {th }}$ century by the Cadbury, when the owner of the organization had planned to invest money for the cultivation of plants in Bernville Cadbury farms. However, this concept gained popularity in the nineteenth century, especially in European countries as well as in the USA. Now a days, this concept has been recognized worldwide (Orlitzky, 2001, Mc William \& Seigel, 2001; Qazi et. Al, 2015 \& Akhtar \& Awan, 2014).

Most of the western countries have a perception about Pakistan that the local companies have no concept of CSR. This exception can be taken as granted since most of the business communities in Pakistan always give profit oriented directions to their organization rather than taking care of social aspects of investment like the interest of stakeholders, environmental friendly policies and employees' welfare etc. The other problem in the country is that most of CEO's and other executives of the organizations are young and inexperienced with 
a little knowledge about CSR. They think that CSR is merely a tool of philanthropy to grab donations etc. (Qazi, et. al, 2015; Yunis, et. al, 2017). However, the Securities Exchange Commission of Pakistan took due cognizance of these anomalies during the Musharraf regime and introduced Securities Acts 2005 and 2007 for the protection of shareholders / stakeholders in the market (Yunis, et. al, 2017 \& Yunis, 2009). In Pakistani dynamics the knowledge of CSR is generally on the bottom line. However, a few companies like Engro and Fauji Fertilizer etc. are contributing substantially towards CSR. Engro's Annual Sustainability reports have full filled almost all the requirements of CSR in case of environmental protection, contribution towards society and welfare of employee at site positions. Similarly, another corporate firm Fauji Group of Companies is also fulfilling the demands of CSR in Pakistan. Except for these firms most of the firms follow the statement "All profit is mine and pollution is yours". Anyhow this aspect needs comprehensive deliberations (NFEH, 2016).

With reference to the above compendium we cannot neglect this problem because foreign companies feel reluctant to enter into Pakistani market with this snag in the hind. Western and Developed countries have the proper setup for CSR. Since every company contribute towards the environment and for society therefore there is a negligible cumulative effect cost effect on the financial performance of the firm. But in case of Pakistan as very few companies contribute towards social welfare aspects therefore such firms suffer enormous loss as compared to the others. It is therefore imperative that the Government must legislate on CSR policies to provide relief and protection to welfare oriented firms (NFEH, 2016). The aim of this research is to provide the valuable knowledge and guidance about the role CSR and its relation with the Firm's Financial performance. The research is based on Pakistani markets where the CSR Practices are not efficient at firm's level. The crux of our research is to apprehend that do CSR effects firm's financial performance or not in Pakistani markets.

\section{Literature Review}

By Akhtar \& Awan (2014), Yunis, et. al, (2017) \& Carroll (1998) Corporate Social Responsibility (CSR) has been encrypted in the Accounting and Management literature for over 45 years. However, firms and societies have substantially enhancedfocus on CSR over the past few years. In order to expand their business companies have evolved such strategies that have taken their business operations from the company into the society. Therefore, the scholars have regardedthesemarket-oriented strategies as companies CSR activities. By Yunis, et. al, (2017) \& Essay UK (2013) the importance of CSR is accepted around the globe. Globalization has changed the concept of modern business practices and business theories. In addition, in the present world the globalization is the process of strengthening and increasing the role of social activities in economic corporations (Essay UK 2013). The above-mentioned trends make corporate world more flexible to run international and domestic businesses. These trends have generated the concept of CSR and also made it more prominent in the present world (Kell, 2016; Scherer \& Palazzo, 2011; Salzmann, Ionescu-Somers, \& Steger, 2005). By Roberts \& Dowling (2002) and Yunis (2009), the concept of CSR was initially originated from the UK and America. Especially in the USA this problem was much debatable in the era of the 1970's and 80 's.

Memon et. al, (2014) solemnly argued in their research that CSR is still a new concept in Pakistan. It should preferably be taught at an academic level in order to flourish it in the country's business organizations. It will directly affect the Firm's hierarchical level. Moreover, they suggested that HEC should also introduce CSR as an academic subject. A case study of Kasur city shows that very little has been invested in the social sector by the business firms. As a result, its soil and underground water have been polluted to a highly dangerous level which is adversely affecting the health of masses and creating multifarious problems for the people.

Theoretical Perspective of CSR and Empirical Findings: There are several theories about CSR, by Friedman (1970); Wright and Ferris (1997) asserted that the implementation of CSR belongs to the agency problem or denoted the interest with managers and shareholders. Similarly, he argued that bad CSR is the conflict of interest between managers and stakeholders if managers are profit-oriented then he follows all profit is mine and the pollution is yours. This argument too muchsatisfied. If manager profit oriented they have a conflict with its stakeholders while if managers are stakeholder oriented they have no conflict and would like to invest on its stakeholders. Waddock and Graves (1997) and Freeman (1984) argued that CSR 
have a significant relation with the firm's financial performance. By Jones (1995) suggested that a firm that conduct its business with collaboration and in the protection of stakeholders bring positive impact on firm's financial performance. The protection of stakeholders by firms will enable the firm to achieve its competitive advantage. Hence all theoretical results in favor of CSR as increase the activity of CSR bring positive change in firm value and firm productivity. A paper published on that topic in 1987 by Malik \& Nadeem, (2014) in that research the authorshave used three dependent variables for to measure firm's financial performance and use three variables like CSR, ROE and ROA. In this paper CSR was measured by reputation index but the authors have allowed the measure of CRS by firms spending on that element. In that research CSR brings positive change in company financial condition. Another research conducted on that topic by Qazi et. al., (2015), the main findings of that paper that most of the organizations even have no knowledge about that field they told that companies heads consider the corporate social responsibilities are just spent money on donations. Note: the second empirical findings are valid, if we check NEHB award-winning corporations of 2016 conference in CSR. We come to know that all award-wining firms put their whole CSR activities under the head of Donation. Perhaps the main reason is that this concept is new in Pakistan. Some of the empirical results suggested that CSR is the tool for commercial success by mean of ethical values like respect employee at workplace, work for communities and introduce environment-friendly policies. By Kiran et. al, (2015) suggested that anincrease in the activity of CSR bring positive change in financial performance of the organization.

\section{Development of Hypotheses}

Hypothesis 1: CSR has a significant relation with firm's financial performance. It will help to firm achieve its competitive advantage in the industry and counter agency problem with its stakeholders (Roberts \& Dowling, 2002; Mc William \& Seigel, 2001)

Hypothesis 2: CSR has no significant relation with firm's financial performance. It will help to firm achieve its competitive advantage in the industry and counter agency problem with its stakeholders (Roberts \& Dowling, 2002; Mc William \& Seigel, 2001)

\section{Econometric Model}

$$
\mathrm{p}\left(\mathrm{Y}=\mathrm{CSR}=1 \text { intercept } \mathbf{X}_{1}+--+\mathbf{X}_{\mathrm{i}}\right)=\frac{1}{\left(1+\mathrm{e}^{-\alpha-\beta \mathbf{X}_{\mathrm{i}}}\right)}-----1
$$

\section{Research Methodology}

Sample and data collection: We use secondary data, time horizon is 2012 to 2016, whole data is selected from the business recorder while the CSR data has been selected from annual reports of the respected organizations. The sample size is limited because most of the firms CSR values have either the stationary issues or have incomplete data. In Pakistan mostly firms contribute in the name of CSR but it is just limited to financial statements, means no more than a financial statement. We drive CSR data from the fiscal report of the firms and spending on CSR in the fiscal year. Furthermore, we use Logistic Regression for analysis.

\section{Measurement of Variables}

Reputation Index: CSR is generally measured by two methods, the first one is the Reputation Index Method whereas the second method is by Content analysis or taking figures from annual reports of the companies. In Reputation Index Method the firms are rated on the basis of multiple dimensions of social performance. The advantages of this method are that one evaluator applies the single criteria to each firm. Whereas the other advantage is that it makes no pretence of applying a rigorous objective measure to a dimension that may naturally be subjective. The first reputation index was used by Council of Economic Priorities (CEP) in the 60s and early 70s (Folger and Nutt, 1975, and Spicer, 1978). Another reputation index is designed by Moskowitz in 1972 and Beresford $(1973,1975,1976)$ ). Our reputation index is based on the ER (employee relations), ENV (Environment), SHA (shareholder relations), PRD (product quality and relations with providers and customers), and COM (community) to measure CSR. We divide the sample companies on Poor CSR companies, Best CSR Companies and Middle Companies on mentioned ratings

Measures of Financial Performance: To measure firm's financial performance we use accounting data, the reason behind that accounting data eliminate distortion from the data and results in this regard three proxies 
have been used. The ratio of operating earnings to the sale which is considered the weak proxy in the empirical research and free from the leverage differences. Earning access value will evaluate the company future aspect if the EV increase it means that firm financial performance increase as an increase in CSR. At the last the operating earnings from asset will evaluate the firms revenue performance. In this study Excess Value (EV) is a measure of financial performance. This measure of performance is used in finance literature, by Thomadakis (1977) as well as Errunza and Senbet (1981). Excess value defined as the difference between total firm market value (market value of equity and book value of debt) and the book value of assets, normalized by sales or, in the absence of wealth transfers of the agency tradition. This measure captures the value premiums or discounts accorded by the market to various companies.

All of these proxies will evaluate the firm's financial performance (Cochran \& Wood, 1984).

- operating income to Asset $=$ opreating income/Asset

- operating income to Sales $=$ opreating income/Sales

- Excess Value $=($ Market Value of Equity + Book value of debt - Total Assets $) /$ sales

\section{Results}

Table 1: CSR by reputation index

\begin{tabular}{|l|r|r|r|}
\hline Dependent Variable: CSR & Worst CSR & \multicolumn{1}{c|}{ Mid CSR } & \multicolumn{1}{c|}{ Best CSR } \\
\hline Variable & Coefficient & Coefficient & \multicolumn{1}{c|}{ Coefficient } \\
\hline C & $(-1.716481)^{* * *}$ & 0.277583 & 0.722671 \\
\hline EV & $(-0.310481)^{* *}$ & $(2.852995)^{*}$ & 0.120236 \\
\hline OPREATING INCOME TO ASSET & -7.212403 & 0.728593 & -0.303702 \\
\hline OPREATING INCOME TO SALE & 2.241732 & -3.975948 & 0.580704 \\
\hline McFadden R-squared & 0.164497 & 0.180597 & 0.008176 \\
\hline S.D. dependent var & 0.351866 & 0.408697 & 0.476557 \\
\hline Akaike info criterion & 0.773219 & 0.927556 & 1.360367 \\
\hline Schwarz criterion & 0.883586 & 1.037923 & 1.470734 \\
\hline Hannan-Quinn criter. & 0.817745 & 0.972082 & 1.404893 \\
\hline Restr. Deviance & 74.64117 & 93.24783 & 116.7479 \\
\hline Log likelihood & -31.18146 & -38.20379 & -57.89669 \\
\hline Deviance & 62.36291 & 76.40758 & 115.7934 \\
\hline Restr. log likelihood & -37.32058 & -46.62391 & -58.37394 \\
\hline Avg. log likelihood & -0.342653 & -0.419822 & -0.636227 \\
\hline LR statistic & 12.27826 & 16.84025 & 0.954494 \\
\hline Prob (LR statistic) & 0.006488 & 0.000762 & 0.812261 \\
\hline Obs with Dep=0 & 78 & 72 & 31 \\
\hline Obs with Dep=1 & 13 & 19 & 60 \\
\hline Total obs & 91 & 91 & 91 \\
\hline
\end{tabular}




\section{EV for Worst, Fair \& Best CSR relation with Excess Earning}
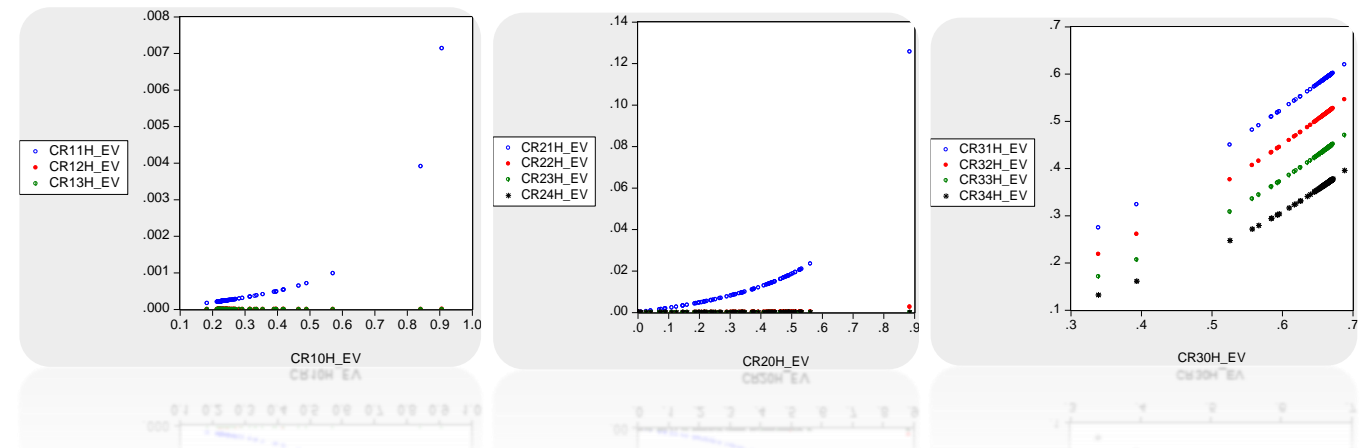

The model one Worst CSR firms explain that an increase in activities of CSR effect firm's financial performance. Worst CSR firm Model has satisfied all statistical tests. The EV have a significant relation with the CSR which interpret that as an increase in CSR brings a negative effect on firm's future prospect as well as firm's revenue, project management, internal management and values. On the other side the logistic regression has also confirmed the aforementioned results that as increase CSR activities in Worst CSR firms bring negativeeffect on the Firm's revenues. More as an increase in CSR activities the curve line shifted down. Middle firm CSR has a positive significant relationship with financial performance indicators. In this section Middle CSR firms have a strong relationship with firms earning excess value. That type of firms explains that as increase one unit of CSR brings the positive impact of firm's future prospect, revenue, efficient internal asset utilization and efficient impact on firm's productivity and internal management efficiency. The graphical results curve is high that explains that EV have significant relation with CSR as one-unit increase in CSR brings sharp impact on firm's financial performance or firms excess value. Best CSR positive relation with the firms financial performance. in this segment the graphical analysis explains that firm's financial indicators have no relationship with Best Firms CSR.

\section{Conclusion and Recommendations}

From the study of the subject it can very conveniently be concluded that increase in CSR activities of those firms which have paid little or no attention towardsCSR at the planning stage of their business, shall have a negative effect on the company's financial performance since it will reduce company's revenue. Whereas the middle CSR firms since have a positive relation with EV, it will therefore enhance the project performance, financial stature and future prospect of the firms. However, the firms with the best CSR will always have a positive relationship with the firm's financial performance but its impact will not beobserved significantly on the firm's financial condition. Since CSR has gained a paramount importance in the modern business world and has become backbone of every industry, therefore in order to ensure nourishing of Pakistani industry on firm footings it is imperative for the government to introduce, Legislation and special training programs on CSR in the form of courses and workshops at institution/university levels.

\section{References}

Akhtar, N. \& Awan, G. A. (2014). The impact of corporate social responsibility (CSR) on profitability firms: A case study of fertilizer \& Cement industry in Southern Punjab, Pakistan International Journal of Development and Economic Sustainability, 2(4), 70-79.

Abboud, L. \& Abdul Razek, T. M. (2010). Social Responsibility and Labor Force: Lebanon Case Study, paper presented to Social Responsibility, Professional Ethics, and Management.

Beresford, D. R. Social responsibility disclosure in 1973 Fortune 500 annual reports. Ernst \& Ernst, (1973).

Beresford, D. R. Social responsibility disclosure-1974 survey of Fortune 500 annual reports. Ernst \& Ernst, (1975). 
Beresford, D. R. Social responsibility disclosure-1975 survey of Fortune 500 annual reports. Ernst \& Ernst, (1976).

Carroll, A. (1998). The four faces of corporate citizenship. Business and Society Review, 100-101(1), 1-7.

Cochran. L. P \& Wood, A. R (1984). Corporate Social Responsibility and Financial Performance. Academy of Management Journal, 27(1), 42-56.

Folger, H. R., \& Nutt, F. (2017-Online). A note on social responsibility and stock valuation. Academy of Management Journal, 18(1), 155-159.

Errunza, V. R., \& Senbet, L. W. (1981). The effects of international operations on the market value of the firm: Theory and evidence. Journal of Finance, 36(2), 401-417.

Freeman, R. (1984). Strategic management: A stakeholder perspective. Englewood Cliffs, NJ: Prentice-Hall.

Friedman, M. (1970). The social responsibility of business is to increase its profits. New York Times, September 13,122-126.

Jones, T. (1995). Instrumental stakeholder theory: A synthesis of ethics and economics. Academy of Management Review, 20, 404-437.

Kell, G. (2016). Everyone benefits from a better world: The role of business in society (1st ed., pp. 4-5). UN: United Nations Global Compact International Yearbook.

Kiran, S., Kakakhel, S., \& Shaheen, F. (2015). Corporate social responsibility and firm profitability: A case of oil and gas sector of Pakistan. City University Research Journal, 5(1), 110-119.

Malik, M. S., \& Nadeem, M. (2014). Impact of corporate social responsibility on the financial performance of banks in Pakistan. International Letters of Social and Humanistic Sciences, 10(1), 9-19.

Margolis, J. D. \& Walsh, J. P. (2001). People and profits: The search for a link between a company's social and financial performance, Lawrence Erlbaum Associates: Mahwah, NJ.

Margolis, J. D. \& Walsh, J. P. (2003). Misery loves companies: Rethinking social initiatives by business, Administrative Science Quarterly, 48, 268-305.

McWilliam, A., Seigel, D. (2001). Corporate Social Responsibility: A theory of Firm Perspective. Academy of Management Review, 26(1), 7-127.

Memon, Z., Wei, Y., Robson, M., \& Khattak, M. (2014). Keeping track of 'corporate social responsibility' as a business and management discipline: the case of Pakistan. Journal of Cleaner Production, 74, 27-34.

Moskowitz, M. (1972). Choosing socially responsible stocks. Business and Society Review, 1,71-75.

NFEH (2016). CSR in Pakistan the good the bad and the ugly. 8th international Summit Award, Vol. 1.

Orlitzky, M., (2001). Does firm size confound the relationship between corporate social performance and financial performance, Journal of Business Ethics, 33, 167-180.

Orlitzky, M., Schmidt, F. L., Rynes, S. L. (2003). Corporate social and financial performance: a meta analysis, Organization Studies, 24, 403-441.

Qazi, W. S, Ahmed, M. Kashif, S., Qureshi, A. Z. (2015). Company's financial performance \& CSR: Pakistan Context. Global Advanced Research Journal of Management and Business Studies, 4(5), 196-202.

Roberts, P. \& Dowling, G. (2002). Corporate reputation and sustained superior financial performance, Strategic Management Journal, 23, 1077-1093.

Salzmann, O., Ionescu-Somers, A., \& Steger, U. (2005). The business case for corporate sustainability. European Management Journal, 23(1), 27-36.

Scherer, A. \& Palazzo, G. (2011). The new political role of business in a globalized world: A review of a new perspective on CSR and its implications for the firm, governance, and democracy. Journal of Management Studies, 48(4), 899-931.

Spicer, B. H. (1978). Investors, corporate social performance and information disclosure: An empirical study. Accounting Review, 53, 94-110.

Thomadakis, S. A. (1977). Value-based test of profitability and the market structure. Review of Economics and Statistics, 59(2), 179-185.

Visser, W. (2008). Corporate social responsibility in developing countries. In Crane, A., Beresford, D. R. Compilation of social measurement disclosures in Fortune 500 annual reports-1973.

Waddock, S., \& Graves, S. (1997). The corporate social performance-financial performance link. Strategic Management Journal, 18, 303-319.

Wright, P., \& Ferris, S. (1997). Agency conflict and corporate strategy: The effect of divestment on corporate value. Strategic management Journal, 18, 77-83.

Yunis, M. S. (2009). CSR research "Back Home": A critical review of the literature and future research options in Pakistan. Business \& Economic Review, 1(1), 1-7. 
Yunis, S. M., Durrani, L. Khan, A. (2017). Corporate Social Responsibility (CSR) in Pakistan: A Critique of the Literature and Future Research Agenda. Business \& Economic Review: 9(1), 65-88.

Annexure

EV for Worst CSR relation with Excess Earning

Worst

\begin{tabular}{|c|c|c|c|c|c|c|c|c|}
\hline \multicolumn{9}{|c|}{ Goodness-of-Fit Evaluation for Binary Specification } \\
\hline \multicolumn{9}{|c|}{ Andrews and Hosmer-Lemeshow Tests } \\
\hline & Quantile of Risk & & & Dep $=0$ & & Dep=1 & Total & H-L \\
\hline & Low & High & Actual & Expect & Actual & Expect & Obs & Value \\
\hline 1 & 0.023 & 0.0381 & 8 & 8.7131 & 1 & 0.2869 & 9 & 1.8304 \\
\hline 2 & 0.0381 & 0.0503 & 8 & 8.6018 & 1 & 0.3983 & 9 & 0.9513 \\
\hline 3 & 0.052 & 0.0709 & 8 & 8.4371 & 1 & 0.5629 & 9 & 0.3621 \\
\hline 4 & 0.0722 & 0.0843 & 9 & 8.2876 & 0 & 0.7125 & 9 & 0.7737 \\
\hline 5 & 0.0864 & 0.0973 & 9 & 8.1622 & 0 & 0.8379 & 9 & 0.9239 \\
\hline 6 & 0.0987 & 0.1108 & 9 & 8.0462 & 0 & 0.9538 & 9 & 1.0669 \\
\hline 7 & 0.1108 & 0.1199 & 7 & 7.9687 & 2 & 1.0313 & 9 & 1.0276 \\
\hline 8 & 0.1239 & 0.1494 & 7 & 7.7662 & 2 & 1.2338 & 9 & 0.5514 \\
\hline 9 & 0.1544 & 0.3043 & 9 & 6.9573 & 0 & 2.0427 & 9 & 2.6425 \\
\hline \multirow[t]{2}{*}{10} & 0.3095 & 0.8042 & 4 & 5.06 & 6 & 4.94 & 10 & 0.4495 \\
\hline & & Total & 78 & 78 & 13 & 13 & 91 & 10.579 \\
\hline \multicolumn{3}{|c|}{ H-L Statistic } & 10.579 & & \multicolumn{2}{|c|}{ Prob. Chi-Sq(8) } & 0.23 & \\
\hline \multicolumn{3}{|c|}{ Andrews Statistic } & 45.36 & & \multicolumn{2}{|c|}{ Prob. Chi-Sq(10) } & $0^{* * * *}$ & \\
\hline
\end{tabular}

\begin{tabular}{|c|c|c|c|c|c|c|c|c|}
\hline \multicolumn{9}{|c|}{ Goodness-of-Fit Evaluation for Binary Specification } \\
\hline \multicolumn{2}{|c|}{ Quantile of Risk } & \multirow[b]{2}{*}{ High } & \multirow[b]{2}{*}{ Actual } & \multicolumn{2}{|c|}{ Dep $=0$} & \multirow{2}{*}{$\begin{array}{l}\text { Dep=1 } \\
\text { Expect }\end{array}$} & \multirow{2}{*}{$\begin{array}{l}\text { Total } \\
\text { Obs }\end{array}$} & \multirow{2}{*}{$\begin{array}{l}\text { H-L } \\
\text { Value }\end{array}$} \\
\hline & & & & Expect & Actual & & & \\
\hline 1 & $3.00 \mathrm{E}-14$ & $9.00 \mathrm{E}-05$ & 9 & 8.9997 & 0 & 0.0003 & 9 & 0.0003 \\
\hline 2 & 0.0001 & 0.0211 & 9 & 8.9383 & 0 & 0.0617 & 9 & 0.0621 \\
\hline 3 & 0.0281 & 0.0968 & 9 & 8.4466 & 0 & 0.5534 & 9 & 0.5896 \\
\hline 4 & 0.0981 & 0.1447 & 8 & 7.8234 & 1 & 1.1766 & 9 & 0.0305 \\
\hline 5 & 0.1514 & 0.2063 & 7 & 7.4628 & 2 & 1.5372 & 9 & 0.1681 \\
\hline 6 & 0.2078 & 0.2274 & 7 & 7.0548 & 2 & 1.9452 & 9 & 0.002 \\
\hline 7 & 0.2376 & 0.2831 & 8 & 6.685 & 1 & 2.315 & 9 & 1.0057 \\
\hline 8 & 0.3172 & 0.344 & 6 & 6.0328 & 3 & 2.9672 & 9 & 0.0005 \\
\hline 9 & 0.3522 & 0.4104 & 3 & 5.5389 & 6 & 3.4611 & 9 & 3.0262 \\
\hline \multirow[t]{2}{*}{10} & 0.4104 & 0.7763 & 6 & 5.0177 & 4 & 4.9823 & 10 & 0.386 \\
\hline & & Total & 72 & 72 & 19 & 19 & 91 & 5.2709 \\
\hline \multicolumn{2}{|c|}{ H-L Statistic } & \multicolumn{3}{|c|}{5.2709} & \multicolumn{2}{|c|}{ Prob. Chi-Sq(8) } & 0.7283 & \\
\hline \multicolumn{2}{|c|}{ Andrews Statistic } & \multicolumn{2}{|r|}{26.703} & & \multicolumn{2}{|c|}{ Prob. Chi-Sq(10) } & $0.0029 * * *$ & \\
\hline
\end{tabular}




\begin{tabular}{|c|c|c|c|c|c|c|c|c|}
\hline \multicolumn{9}{|c|}{ Goodness-of-Fit Evaluation for Binary Specification } \\
\hline \multicolumn{3}{|c|}{ Quantile of Risk } & \multirow[b]{2}{*}{ Actual } & \multicolumn{2}{|c|}{ Dep $=0$} & \multirow{2}{*}{$\begin{array}{l}\text { Dep=1 } \\
\text { Expect }\end{array}$} & \multirow{2}{*}{$\begin{array}{l}\text { Total } \\
\text { Obs }\end{array}$} & \multirow{2}{*}{$\begin{array}{l}\mathrm{H}-\mathrm{L} \\
\text { Value }\end{array}$} \\
\hline & & High & & Expect & Actual & & & \\
\hline 1 & 0.2917 & 0.6486 & 4 & 3.8868 & 5 & 5.1132 & 9 & 0.0058 \\
\hline 2 & 0.6499 & 0.655 & 2 & 3.1299 & 7 & 5.8701 & 9 & 0.6254 \\
\hline 3 & 0.6566 & 0.6616 & 2 & 3.0645 & 7 & 5.9355 & 9 & 0.5607 \\
\hline 4 & 0.6618 & 0.664 & 1 & 3.0317 & 8 & 5.9683 & 9 & 2.0531 \\
\hline 5 & 0.664 & 0.6665 & 0 & 3.0135 & 9 & 5.9865 & 9 & 4.5305 \\
\hline 6 & 0.6665 & 0.6677 & 3 & 2.9957 & 6 & 6.0043 & 9 & \#\#\#\#\#\# \\
\hline 7 & 0.668 & 0.6694 & 7 & 2.9818 & 2 & 6.0182 & 9 & 8.0977 \\
\hline 8 & 0.6695 & 0.6718 & 8 & 2.9614 & 1 & 6.0386 & 9 & 12.777 \\
\hline 9 & 0.6723 & 0.6799 & 4 & 2.9166 & 5 & 6.0834 & 9 & 0.5954 \\
\hline \multirow[t]{2}{*}{10} & 0.6804 & 0.7371 & 0 & 3.0181 & 10 & 6.9819 & 10 & 4.3228 \\
\hline & & Total & 31 & 31 & 60 & 60 & 91 & 33.568 \\
\hline \multicolumn{2}{|c|}{ H-L Statistic } & \multicolumn{3}{|c|}{33.568} & \multicolumn{2}{|c|}{ Prob. Chi-Sq(8) } & 0 & \\
\hline \multicolumn{2}{|c|}{ Andrews Statistic } & \multicolumn{2}{|r|}{37.847} & & \multicolumn{2}{|c|}{ Prob. Chi-Sq(10) } & $0 * * *$ & \\
\hline
\end{tabular}

